\title{
Pengaruh Variabel Demografi Terhadap Pertumbuhan Ekonomi Provinsi Nusa Tenggara Barat Tahapan Menuju Bonus Demografi
}

\section{Gusti Ayu Arini,Taufiq Chaidir,Satarudin,Siti Sriningsih}

Universitas Mataram

\begin{tabular}{l|l}
\hline ART ICLE INFO & Received : 29 Januari 2018; Accepted: 29 Februari 2018; Published: Maret 2018 \\
\hline & ABSTRACT : The study entitled The Influence of Demographic Variables on the
\end{tabular}

Keywords :

Population growth, employment, dependency ratio, female labor force participation rate, economic growth

ABSTRACT : The study entitled The Influence of Demographic Variables on the Economic Growth of the Province of West Nusa Tenggara towards the Demogerafi Bonus aims to analyze the variables of population growth, number of workers, dependency ratio, the level of participation of women labor force towards economic growth in West Nusa Tenggara province. This type of research is descriptive research and uses secondary data for the period 2009-2016. To analyze the relationship of variables Population growth, labor, dependency ratio and the level of participation of the female labor force towards the economic growth of the province of West Nusa Tenggara were used multiple linear regression model with the Ordinary Least Square (OLS) method. The results obtained from this regression for the population growth variable (X1) and dependency ratio (X3) have a negative slope giving meaning if there is an increase in population growth and dependency ratio, there is a tendency to decrease economic growth while for the variable labor (X2) and participation rate the female workforce $(X 4)$ has a positive slope giving meaning, if there is an increase in the number of workers and the level of participation of the female workforce, there is a tendency to increase economic growth. The test is partially and simultaneously all significant. The level of suitability (the goodness of fit) of the observed estimation model is indicated by the coefficient of determination (R2) of 0.894. This means that the ability and contribution of the independent variables observed in the dependent variable is 89.4 percent while the remaining 10.6 percent is outside the model.

Kata Kunci : Pertumbuhan penduduk, jumlah tenaga kerja, dependency ratio, tingkat partisipasi angkatan kerja wanita, pertumbuhan ekonomi
ABSTRAK : Kajian yang berjudul Pengaruh Variabel Demografi terhadap Pertumbuhan Ekonomi Provinsi Nusa Tenggara Barat tahapan Menuju Bonus Demogerafi bertujuan untuk menganalisis variabel pertumbuhan penduduk, jumlah tenaga kerja, dependency ratio, tingkat partisipasi angkatan kerja wanita terhadap pertumbuhan ekonomi provinsi Nusa Tenggara Barat . Jenis penelitian ini merupakan penelitian deskriftif dan menggunakan data sekunder kurun waktu 2009 -2016. Untuk menganalisis hubungan variable Pertumbuhan penduduk, tenaga kerja, dependency ratio dan tingkat partisipasi angkatan kerja wanita terhadap pertumbuhan ekonomi propinsi Nusa Tenggara Barat digunakan model regresi linier berganda dengan metode Ordinary Least Square (OLS). Hasil yang diperoleh dari regresi ini untuk variabel pertumbuhan penduduk (X1) dan dependency ratio (X3) mempunyai slope yang negatif memberikan makna jika terjadi peningkatan pertumbuhan penduduk dan dependency ratio maka terdapat kecenderungan penurunan pertumbuhan ekonomi sedangkan untuk variabel tenaga kerja (X2) dan tingkat partisipasi angkatan kerja wanita (X4) mempunyai slope yang positip memberikan makna, jika terjadi peningkatan jumlah tenaga kerja dan tingkat partisipasi angkatan kerja wanita maka terdapat kecenderungan peningkatan pertumbuhan ekonomi. Uji secara parsial dan simultan seluruhnya signifikan.. Tingkat kesesuaian (the goodness of fit) dari model estimasi yang diamati ditandai dengan nilai koefisien determinasi (R2) sebesar 0,894. Ini berarti kemampuan dan kontribusi dari variabel bebas yang diamati terhadap variabel terikat sebesar 89,4 persen sedangkan sisanya sebesar 10,6 persen di luar model.

Corresponding Author:

Alamat : Program Studi Ekonomi Pembangunan, Fakultas Ekonomi dan Bisnis, Universitas Mataram, Jln. Majapahit No. 62 Mataram.

e-mail: gstarini66@gmail.com 


\section{PENDAHULUAN}

\section{Latar Belakang}

Dalam suatu proses pembangunan, peranan penduduk sangat penting. Penduduk sebagai sumberdaya manusia merupakan salah satu faktor produksi yang akan memberikan kontribusinya dalam pembangunan ekonomi. Berbagai pendapat mengenai keterkaitan jumlah penduduk dengan pembangunan ekonomi, disatu sisi kelompok yang optimis berpendapat jumlah penduduk yang besar merupakan suatu asset bagi suatu negara, disisi yang lain kelompok pisimis berpendapat jumlah penduduk yang besar akan menjadi beban negara. Jumlah penduduk yang besar bagaikan pisau bermata dua.

Keberhasilan program Keluarga berencana yang diterapkan di Indonesia berdampak pada berkurangnya angka fertilitas(kelahiran). Dalam jangka panjang terjadinya penurunan angka fertilitas akan mempengaruhi jumlah dan komposisi penduduk. Komposisi penduduk menurut umur disebut juga struktur penduduk. Perubahan struktur penduduk ini ditandai dengan semakin bertambahnya usia penduduk yang produktif dibandingkan dengan penduduk usia muda dan lanjut usia. Fenomena ini menandai Indonesia mendapatkan bonus demografi. Data Badan Pusat Statistik (BPS), dependency ratio Indonesia tahun 2010 sebesar 50,5. Pada tahun 2015 mengalami penurunan menjadi 48,6. Diproyeksikan angka dependency ratio ini akan semakin kecil lagi pada tahun 2020 (47,7), tahun 2025 $(47,2)$ dan tahun 2030 (46,9). Dengan bonus demografi yang akan diterima Indonesia tahun 2020-2030, merupakan peluang untuk mencapai pertumbuhan ekonomi yang tinggi .

Era bonus demografi ini datangnya berbeda-beda untuk setiap provinsi, tergantung pada kondisi struktur umur penduduknya. Provinsi Nusa Tenggara Barat memiliki peluang yang cukup besar dalam memanfaatkan bonus demografi ini untuk memacu pertumbuhan ekonominya. Berdasarkan buku Proyeksi Penduduk Indonesia 2010 - 2035, hasil proyeksi penduduk NTB untuk tingkat fertilitasnya kecenderungan menurun dari tahun $2010(2,72)$ dan tahun $2035(2,09)$. Diproyeksikan pada tahun 2035 penduduk NTB berjumlah 5,75 juta jiwa, penduduk berjenis kelamin perempuan lebih besar jumlahnya.. Berdasarkan data proyeksi penduduk,Provinsi NTB diperkirakan mengalami kondisi bonus demografi diperkirakan tahun 2030 yaitu ketika angka dependency ratio berada di angka 
48,6 persen. Penduduk usia produktif NTB diperkirakan 67,3 persen dan penduduk usia non produktif berjumlah sekitar 32,7 persen.

Propinsi NTB akan mengalami keadaan bonus demografi sekitar 13 tahun lagi. Untuk itu perlu dipersiapkan sumberdaya manusia yang berkualitas, dari segi pendidikan dan kesehatannya,agar peluang ini dapat meningkatkan perekonomian NTB. Rendahnya angka dependency ratio akan memberikan keuntungan bagi perekonomian NTB jika dimanfaatkan secara optimal. Menurut Adioetomo, Sri Moertiningsih (2005), ada 3 hal yang harus diperhatikan oleh .pemerintah daerah dalam menghadapi bonus demografi, yaitu terkait dengan penawaran tenaga kerja, partisipasi perempua dalam pasar kerja, dan tabungan. Semakin berkualitas, SDM akan semakin produktif serta diikuti dengan dependency ratio yang rendah maka perekonomian NTB akan meningkat dengan cepat.

\section{Perumusan Masalah}

Untuk memanfaatkan peluang bonus demografi bagi pertumbuhan ekonomi di Provinsi NTB perlu dipersiapkan dengan perencanaan yang baik., Peningkatan kualitas sumberdaya manusia disertai dengan perluasan kesempatan kerja pada semua sektor akan mendorong perekonomian NTB menjadi lebih maju. Dari sisi demografi, dengan menggunakan berbagai variabel demografi yang ada mencoba untuk mengkaji keterkaitan berbagai variabel demografi dengan pertumbuhan ekonomi.

Untuk itu perlu dirumuskan permasalahan sebagai berikut :

1. Apakah variabel pertumbuhan penduduk, tenaga kerja, dependency ratio dan tingkat partisipasi angkatan kerja perempuan mempengaruhi pertumbuhan ekonomi provinsi NTB tahun 2009 - 2016

2. Variabel demografi yang mana paling dominan mempengaruhi pertumbuhan ekonomi provinsi NTB tahun 2009 - 2016

\section{Variabel Penelitian}

Variabel -variabel yang digunakan dalam penelitian ini adalah :

1. Pertumbuhan Ekonomi

2. Pertumbuhan penduduk

3. Tenaga Kerja

4. Dependency Ratio

5. Tingkat partisipasi angkatan kerja wanita

\section{Klasifikasi variabel}

Dalam penelitian ini, variabel diklasifikasikan menjadi 2 yaitu: 
1. Variabel dependen (variabel terikat) yaitu variabel yang nilainya dipengaruhi oleh variabel lain . Dalam penelitian ini yang menjadi variabel terikat adalah pertumbuhan ekonomi

2. Variabel independen (variabel bebas) yaitu variabel yang nilainya mempengaruhi variabel lain. Dalam penelitian ini yang menjadi variabel bebas adalah pertumbuhan penduduk, Tenaga kerja, dependency ratio dan tingkat partisipasi angkatan kerja wanita.

\section{Definisi Operasional Variabel}

1. Pertumbuhan Ekonomi dinyatakan sebagai perubahan PDRB atas dasar harga konstan di Provinsi NTB tahun 2009-2016 dinyatakan dalam satuan persen

2. Pertumbuhan penduduk adalah perubahan jumlah penduduk atau populasi di provinsi NTB yang dapat diukur dari tahun 20092016dinyatakan dalam satuan persen

3. Tenaga Kerja adalah penduduk usia kerja 15 - 64 tahun yang berdomisili diwilayah provinsi NTB dari tahun 2009-2016 dinyatakan dalam satuan orang
4. Dependency Ratio adalah perbandingan jumlah penduduk usia produktif dengan usia tidak produktif yang berdomisili di wilayah provinsi NTB dari tahun 2009-2016 dinyatakan dalam satuan persen

5. Tingkat partisipasi angkatan kerja wanita adalah banyaknya angkatan kerja wanita yang ikut berpartisipasi dalam berbagai kegiatan sektor ekonomi di provinsi NTB dari tahun 2009-2016dinyatakan dalam satuan persen

Analisis yang digunakan dalam penelitian ini adalah analisis secara deskriptif khususnya data-data yang bersifat kualitatif dan juga dilakukan analisis secara kuantitatif.

Untuk menganalisis hubungan variable Pertumbuhan penduduk, tenaga kerja, dependency ratio dan tingkat partisipasi angkatan kerja wanita terhadap pertumbuhan ekonomi propinsi Nusa Tenggara Barat digunakan model regresi linier berganda dengan metode Ordinary Least Square (OLS) untuk mengestimasi persamaan-persamaan sebagai berikut : 
1. $G D P=b_{0}+b_{1} X 1+b_{2} X_{2}+b_{3} X_{3}+b_{4} X_{4}+u_{i}$ dimana :

$$
\begin{array}{ll}
\text { GDP }(\mathrm{Y}) & =\text { Pertumbuhan ekonomi } \\
\mathrm{X}_{1} & =\text { Pertumbuhan penduduk } \\
\mathrm{X}_{2} & =\text { Tenaga kerja } \\
\mathrm{X}_{3} & =\text { Dependency ratio } \\
\mathrm{X}_{4} & =\text { Tingkat partisipasi angkatan } \\
& \text { kerja wanita }
\end{array}
$$

Untuk menguji ketepatan model dan pengaruh variabel bebas terhadap variabel terikat secara parsial dan simultan digunakan uji statistik $t$ dan $F$ dengan formulasi sebagai berikut : (Gujarati, 1995, ramanathan, 1995)

1. Pengujian hipotesis secara parsial digunakan uji statistik $\mathrm{t}$

$$
t=\frac{\beta_{i}}{\operatorname{Se}\left(\beta_{i}\right)}
$$

Langkah-langkah pengujian ,

a. Formulasi hipotesis

$\mathrm{H}_{0}: \beta_{\mathrm{i}}=0$; artinya tidak ada pengaruh yang signifikan masingmasing variabel bebas terhadap variabel terikat.

$H_{A}: \beta_{i} \neq 0$; artinya ada pengaruh yang signifikan masing-masing variabel bebas terhadap variabel terikat.

b. Menentukan $\alpha$ (5 \%); degree of freedom (df) $n-k$

c. Kriteria pengujian $-\mathrm{t}_{\alpha / 2} ; \mathrm{df} \leq \mathrm{t}$ statistik $\leq+\mathrm{t}_{\alpha / 2} \quad ; \mathrm{df}$

untuk menerima hipotesis nol $\left(\mathrm{H}_{0}\right)$.

$\mathrm{t}$ statistik $\left\langle-\mathrm{t}_{\alpha / 2} ; \mathrm{df}\right.$ atau $\mathrm{t}$ statistik $\rangle \mathrm{t}_{\alpha / 2} ; \mathrm{df}$ , untuk menerima hipotesis alternatif $\left(\mathrm{H}_{\mathrm{A}}\right)$.

d. Menghitung nilai t, dengan formula :

$$
t=\frac{\beta_{i}}{\operatorname{Se}\left(\beta_{i}\right)}
$$

e. Menarik kesimpulan.

2. Pengujian hipotesis secara simultan, digunakan pendekatan $\mathrm{F}$ statistik.

$$
F=\frac{R^{2} /(k-1)}{\left(1-R^{2}\right) /(n-k)}
$$

Langkah -langkah pengujian,

a. Formulasi hipotesis.

$\mathrm{H}_{0}$ : semua variabel bebas $=0$

Artinya tidak ada pengaruh yang signifikan seluruh variabel bebas terhadap variabel terikat

$H_{A}$ : semua variabel bebas $\neq 0$

Artinya ada pengaruh yang signifikan seluruh variabel bebas terhadap variabel terikat.

b. Menentukan $\alpha(5 \%)$; degree of freedom (df) k-1;n-k.

c. Kriteria pengujian : F stat $\leq F \alpha ; d f(k-1) ;(n-k)$ untuk menerima hipotesis nol $\left(\mathrm{H}_{0}\right)$ 
F stat $>F \alpha ; d f(k-1) ;(n-k)$ untuk menerima hipotesis alternatif $\left(\mathrm{H}_{\mathrm{A}}\right)$.

d. Menghitung nilai F, dengan formula :

$$
F=\frac{R^{2} /(k-1)}{\left(1-R^{2}\right) /(n-k)}
$$

e. Menarik kesimpulan.

3. Untuk kesesuaian atau uji tingkat kesesuaian (Tes Goodness of Fit) ditandai dengan menggunakan pendekatan koefisien determinasi $\left(R^{2}\right)$, yang menerangkan besarnya variasi di dalam variabel penjelas (variabel terikat) yang mampu diterangkan oleh variabel bebas.

Besarnya $\mathrm{R}^{2}$ diformulasikan sebagai berikut :

$$
R^{2}=1-\frac{J K K}{J K T}
$$

JKK = jumlah kuadrat kesalahan.

JKT = jumlah kuadrat total.

\section{Pembahasan}

\section{Gambaran umum Nusa Tenggara Barat} Geografi dan Pemerintahan

Provinsi Nusa Tenggara Barat terdiri atas 2 (dua) pulau besar yaitu Pulau Lombok dan Pulau Sumbawa dan ratusan pulau-pulau kecil. Dari 279 pulau yang ada, terdapat 44 pulau yang telah berpenghuni. Luas wilayah Provinsi Nusa
Tenggara Barat mencapai 20.153,20 km2. Terletak antara 115046'- 11905' Bujur Timur dan 8010'-905' Lintang Selatan. Luas Pulau Sumbawa mencapai 15.414,5 km2 (76,49 \%) atau 2/3 dari luas Provinsi Nusa Tenggara Barat, dan luas Pulau Lombok hanya mencapai $1 / 3$ saja. Pusatpemerintahan Provinsi NTB terdapat di Kota Mataram Pulau Lombok.

Provinsi Nusa Tenggara Barat terdiri dari 8 kabupaten, 2 kota, 116 kecamatan dan 1.141 desa/ kelurahan. Kabupaten Sumbawa memiliki kecamatan terbanyak, yaitu 24 kecamatan. Sedangkan Kabupaten Lombok Timur memiliki wilayah administrasi desa/kelurahan terbanyak dengan 254 desa/kelurahan dengan jumlah kecamatan sebesar 20 kecamatan. Jumlah seluruh kecamatan di Pulau Sumbawa sebanyak 63 kecamatan, lebih banyak dari Pulau Lombok sebanyak 54 kecamatan sedangkan untuk jumlah desa/kelurahan berbanding terbalik dengan jumlah seluruh kecamatan di Pulau Sumbawa. Jumlah seluruh desa/ kelurahan di Pulau Lombok ada 598 desa/kelurahan lebih banyak dari Pulau Sumbawa sebanyak 548 desa/ kelurahan (NTB dalam angka 2017)

\section{Kependudukan dan Ketenagakerjaan}

Berdasarkan data Proyeksi Penduduk tahun 2010 - 2020 jumlah penduduk Nusa 
Tenggara Barat Tahun 2016 mencapai 4.896.162 jiwa. Dengan rincian, laki-laki sebanyak 2.375.750 jiwa dan perempuan sebanyak 2.520.412 jiwa, dengan rasio jenis kelamin sebesar 94,26. Jumlah penduduk terbesar terdapat di Kabupaten Lombok Timur dan yang terkecil di Kabupaten Sumbawa Barat. Jumlah rumahtangga di Provinsi NTB adalah 1.360.627 rumahtangga dengan rata-rata anggota rumahtangga sebesar 3,6 orang. Bila dilihat menurut kelompok umur. komposisi penduduk Provinsi NTB berbentuk pyramid dengan komposisi penduduk terbanyak pada umur $0-4$ tahun yaitu sebanyak 503.860 jiwa. terkecil pada kelompok umur $60-64$ tahun . Jumlah angkatan kerja NTB mencapai 2.464.331 orang. Penduduk yang bekerja mencapai 2.367.310 orang. Sekolah 306.812 orang. Mengurus Rumah Tangga 546.728 orang dan sisanya mencari pekerjaan dan penerima pendapatan

Jumlah penduduk dan rasio jenis kelamin untuk masing-masing kabupaten/kota di provinsi Nusa Tenggara Barat tahun 2016 dapat dilihat pada tabel berikut ini :

Tabel Jumlah Penduduk dan Rasio Jenis Kelamin Menurut Kabupaten /Kota di Provinsi Nusa Tenggara Barat Tahun 2016

\begin{tabular}{|l|c|c|}
\hline Kabupaten/Kota & Jumlah Penduduk (orang) & Rasio Jenis Kelamin \\
\hline \multicolumn{1}{|c|}{ Kabupaten } & & \\
\hline 1. Lombok Barat & 665.132 & 95,67 \\
\hline 2. Lombok Tengah & 922.088 & 89,76 \\
\hline 3. Lombok Timur & 1.173 .781 & 87,14 \\
\hline 4. Sumbawa & 445.503 & 104,19 \\
\hline 5. Dompu & 241.888 & 102,04 \\
\hline 6. Bima & 473.890 & 99,14 \\
\hline 7. Sumbawa Barat & 137.072 & 102,78 \\
\hline 8. Lombok Utara & 214.393 & 97,30 \\
\hline & & 97,80 \\
\hline 9. Mataram & 459.314 & 96,51 \\
\hline 10. Bima & 163.101 & 94,26 \\
\hline Nusa Tenggara Barat & 4.896 .162 & \\
\hline
\end{tabular}

Sumber : NTB dalam angka 2017

Berdasarkan kelompok umur, jumlah penduduk dibedakan menjadi kelompok umur 0 - 14 tahun, 15 - 64 tahun dan 65 tahun keatas. Pengelompokan ini dilakukan untuk mengetahui besarnya angka beban tanggungan atau dependency ratio. Rasio ketergantungan (dependency ratio) dapat digunakan sebagai indikator yang secara kasar dapat menunjukkan keadaan ekonomi suatu 
negara apakah tergolong negara maju atau negara yang sedang berkembang. Dependency ratio merupakan salah satu indikator demografi yang penting. Semakin tingginya persentase dependency ratio menunjukkan semakin tingginya beban yang harus ditanggung penduduk yang produktif untuk membiayai hidup penduduk yang belum produktif dan tidak produktif lagi.

Tabel Angka Beban Tanggungan /Dependency Ratio Provinsi NTB Tahun 2016

\begin{tabular}{|c|c|c|c|}
\hline \multirow{2}{*}{ Kelompok Umur } & \multicolumn{2}{|c|}{ Jenis Kelamin } & \multirow{2}{*}{ Jumlah } \\
\cline { 2 - 3 } & Laki-laki & Perempuan & \\
\hline $0-14$ & 746.262 & 715.539 & 1.461 .801 \\
\hline $15-64$ & 1.517 .829 & 1.674 .396 & $3,192.225$ \\
\hline $65+$ & 111.659 & 297.050 & 408.709 \\
\hline Angka Beban Tanggungan & 56,52 & 60,47 & 58,60 \\
\hline
\end{tabular}

Sumber : NTB dalam angka 2017

Tabel diatas memberikan informasi mengenai kondisi ketenagakerjaan di provinsi Nusa Tenggara Barat terkait dengan dependency ratio. Dependency ratio memberikan gambaran mengenai perbandingan antara jumlah penduduk berumur 0-14 tahun, ditambah dengan jumlah penduduk 65 tahun keatas dibandingkan dengan jumlah penduduk usia 15-64 tahun. Dependency ratio provinsi Nusa Tenggara Barat untuk tahun 2016 sebesar 58, 60. Jika ditelusuri berdasarkan jenis kelamin nya maka dependency ratio perempuan $(60,47)$ lebih tinggi daripada laki-laki $(56,52)$
Sedangkan persentase dependency ratio yang semakin rendah menunjukkan semakin rendahnya beban yang ditanggung penduduk yang produktif untuk membiayai penduduk yang belum

Untuk tahun 2016 besarnya angka beban tanggungan / dependency ratio dapat dilihat pada tabel berikut ini : produktif dan tidak produktif lagi. 
ceteris paribus maka seiring dengan peningkatan pertumbuhan penduduk terdapat kecenderungan penurunan pertumbuhan ekonomi. Kondisi yang sama terjadi pada variabel dependency ratio (X3) adalah - 6,263, jika pertumbuhan penduduk, tenaga kerja dan tingkat partisipasi angkatan kerja wanita ceteris paribus maka seiring dengan peningkatan dependency ratio terdapat kecenderungan penurunan pertumbuhan ekonomi. Untuk variabel tenaga kerja (X2) adalah sebesar 0,0000067, jika pertumbuhan penduduk, dependency ratio dan tingkat parisipasi angkatan kerja wanita ceteris paribus maka seiring dengan peningkatan jumlah tenaga kerja terdapat kecenderungan peningkatan pertumbuhan ekonomi. Terakhir untuk variabel yang keempat adalah variabel tingkat partisipasi angkatan kerja wanita (X4) sebesar 5,651, jika pertumbuhan penduduk, tenaga kerja dan dependency ratio ceteris paribus maka seiring dengan peningkatan tingkat partisipasi angkatan kerja wanita terdapat kecenderungan peningkatan pertumbuhan ekonomi.

\section{Pengujian Hipotesis Secara Individu/ Parsial (Uji t)}

Pengujian hipotesis dari ke- empat variabel yakni pertumbuhan penduduk $(\mathrm{X} 1)$, tenaga kerja $(\mathrm{X} 2)$, dependency ratio
(X3) dan tingkat partisipasi angkatan kerja wanita (X4) secara individu atau parsial yang ditunjukkan oleh $\mathrm{t}$ hitung dari masing-masing variabel yaitu - 2,761 (X1), 4,366 (X2) , -4,434 (X3) dan 3,743 (X4) dengan menggunakan taraf nyata sebesar 5 persen maka nilai $t$ tabel adalah $+1,96$. Jika nilai $t$ hitung dari masingmasing variabel dibandingkan dengan $\mathrm{t}$ tabelnya maka dapat disimpulkan bahwa hipotesis alternatif untuk ke-empat variabel tersebut diterima artinya variabel pertumbuhan penduduk, tenaga kerja, dependency ratio dan tingkat partisipasi berpengaruh signifikan terhadap pertumbuhan ekonomi propinsi Nusa Tenggara Barat.

\section{Pengujian Hipotesis Secara Serempak} /Simultan (Uji F)

Pengujian secara serempak (simultan) bertujuan untuk mengetahui apakah seluruh variabel yang diestimasi dan masuk dalam model pengamatan berpengaruh signifikan atau tidak signifikan. Nilai $F$ hitung sebagai representasi pengujian secara simultan diperoleh sebesar 6,319. Dengan menggunakan taraf nyata sebesar 5 persen pada derajad bebas ( $k-1)$ dan ( $n$ - k ) diperoleh F tabel sebesar 2,49.. dapat disimpulkan nilai $F$ hitung ( $F$ statistik ) lebih besar dibandingkan dengan $\mathrm{F}$ tabel 
$(6,319>2,49)$. Ini berarti Ha diterima yang memberikan makna bahwa seluruh variabel bebas yaiti pertumbuhan penduduk, tenaga kerja, dependency ratio dan tingkat partisipasi angkatan kerja wanita berpengaruh signifikan terhadap pertumbuhan ekonomi propinsi Nusa Tenggara Barat.

Dengan mencermati hasil kajian ini menngunakan data sekunder selama 8 tahun dengan variabel laju pertumbuhan [enduduk, tenaga kerja, dependency ratio dan tingkat partisipasi angkatan kerja wanita merupakan variabel yang predictive relevant terhadap pertumbuhan ekonomi.

Tingkat kesesuaian (the goodness of fit) dari model estimasi yang diamati ditandai dengan nilai koefisien determinasi (R2) sebesar 0,894. Ini berarti kemampuan dan kontribusi dari variabel bebas yang diamati terhadap variabel terikat sebesar 89, 4 persen sedangkan sisanya sebesar 10,6 persen di luar model.

\section{SIMPULAN}

1. Untuk variabel pertumbuhan penduduk (X1) dan dependency ratio
(X3) mempunyai slope yang negatif memberikan makna jika terjadi peningkatan pertumbuhan penduduk dan dependency ratio maka terdapat kecenderungan penurunan pertumbuhan ekonomi, Untuk variabel tenaga kerja (X2) dan tingkat partisipasi angkatan kerja wanita (X4) mempunyai slope yang positip memberikan makna, jika terjadi peningkatan jumlah tenaga kerja dan tingkat partisipasi angkatan kerja wanita maka terdapat kecenderungan peningkatan pertumbuhan ekonomi.

2. Uji secara parsial dan simultan seluruhnya signifikan

3. Tingkat kesesuaian (the goodness of fit) dari model estimasi yang diamati ditandai dengan nilai koefisien determinasi (R2) sebesar 0,894. Ini berarti kemampuan dan kontribusi dari variabel bebas yang diamati terhadap variabel terikat sebesar 89,4 persen sedangkan sisanya sebesar 10,6 persen di luar model.

\section{DAFTAR PUSTAKA}

Arfida BR, 2003, Ekonomi Sumber Daya Manusia, Ghalia Indonesia, Jakarta.

Adioetomo, Sri Moertiningsih. 2005. Bonus Demografi. Menjelaskan Hubungan Antara Pertumbuhan Penduduk Dengan Pertumbuhan Ekonomi. Pidato Disampaikan 
pada Upacara Pengukuhan Jabatan Guru Besar Tetap Dalam Bidang Ekonomi Kependudukan pada Fakultas Ekonomi Universitas Indonesia. Universitas Indonesia, Jakarta.

Adioetomo, Sri Moertiningsih dan Samosir, Omas Bulan. 2010. Dasar-dasar Demografi. Lembaga Demografi Fakultas Ekonomi Universitas Indonesia, Salemba Empat, Jakarta.

Badan Pusat Statistik. 2000. Penduduk Indonesia: Hasil Sensus Penduduk 2000. Badan Pusat Statistik, Jakarta. 2010. Penduduk Indonesia Menurut Provinsi dan Kabupaten/Kota Sensus Penduduk 2010. Badan Pusat Statistik, Jakarta. 2012. Estimasi Parameter Demografi: Tren Fertilitas, Mortalitas, dan Migrasi. HasilSensus Penduduk 2010. Badan Pusat Statistik, Jakarta. 2015, Ragam Statistik Nusa Tenggara Baratm Edisi 1, BPS NTB 2010-2017, Nusa Tenggara Barat Dalam angka, BPS NTB

Badan Pusat Statistik, Bappenas, UNFPA. 2005. Proyeksi Penduduk Indonesia 2000-2025. Badan Pusat Statistik, Jakarta.

Badan Pusat Statistik, BKKBN, Kemenkes, and Macro International Inc.. 1992. Survei Demografi dan Kesehatan Indonesia 1991. Badan Pusat Statistik, Jakarta.

Hesti W, Nani S, 2016, Mengukur Peluang dan Ancaman Bonus Demografi Terhadap Kualitas Sumberdaya Manusia Dalam Pembangunan Ekonomi Di Bandar Lampung, Jurnal Bisnis Darmajaya, Vol.2 No.01,Januari 2016

Muh Mahdi Kharis, 2011, Pengaruh Faktor-Faktor Kependudukan Terhadap Pertumbuhan Ekonomi Di Kabupaten Pemalang, Semarang

Mudrajad Kuncoro, 1997, Ekonomi Pembangunan: Teori, Masalah dan Kebijakan, YKPN, Yogyakarta.

Mulyadi S, 2003, Ekonomi Sumber Daya Manusia Dalam Perspektif Pembangunan, PT RajaGrafindo Persada, Jakarta

Nazir, Moh, 1999, Metode Penelitian, Ghalia Indonesia, Jakarta

Sonny Sumarsono, 2009, Teori dan Kebijakan Publik Ekonomi Sumber Daya Manusia, Graha Ilmu, Yogyakarta

Valeria Claradiva, Pengaruh Variabel Demografi Pertumbuhan Ekonomi Di Kabupaten dan Kota Provinsi Sumatera Barat periode Tahun 2010 -2015. Universitas Andalas Padang 